\title{
Prospective Randomized Controlled Study of Efficacy of Self Gripping Mesh in Inguinal Hernia Repair
}

\author{
MOHAMMED A. ELHARTY, M.Sc.; MOHAMED A. MOHAMED, M.D.; AYMAN A.ELNEMR, M.D. and \\ AHMED A. DARWISH, M.D.
}

The Department General Surgery, Faculty of Medicine, Tanta University, Egypt

\begin{abstract}
Background: Chronic pain following inguinal hernia repair is a complex problem. Mesh fixation with sutures may be a contributing factor to this pain. A new self gripping mesh

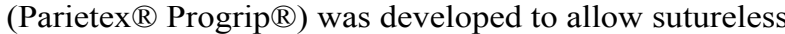
fixation of mesh, avoid chronic pain after hernia surgery and reduce the operative time.
\end{abstract}

Aim of the Work: The aim of this study was to study the efficacy of self gripping mesh in inguinal hernia repair. Methods: Twenty six male patients with uncomplicated inguinal hernia were randomized into 2 groups. Group A: Included 10 patients subjected to repair with polypropylene mesh. Group B: Included 16 patients subjected to repair with parietex ${ }^{\circledR}$ progrip ${ }^{\circledR}$ mesh. They were followed-up for incidence of pain (with VAS) and integrity of the mesh (with U/S).

Results: There were no statistically significant differences between both groups regarding age, sex, body mass index or incidence of postoperative pain $(p=0.385)$. The operative time and mesh fixation time were significantly shorter in self gripping mesh group than the sutured mesh group $(p<0.001)$. There were no reported cases of recurrence, haematoma, epididymo-orchitis or testicular atrophy in either group during the follow-up period. Scrotal oedema was detected in 7 cases in group A and 4 cases in group B. Seroma was detected in 3 cases in group A and 2 cases in group B. Wound infection occurred in 2 cases in group A.

Conclusion: The higher price of the parietex progrip mesh makes its use questionable. The smaller number of the studied cases with the short follow-up period make us unable to give solid recommendation to use one mesh type than the other.

Key Words: Inguinal - Hernia repair - Progrip mesh.

\section{Introduction}

LICHTENSTEIN tension free mesh repair is the most commonly used technique for open inguinal hernia. The ideal outcome in inguinal hernia surgery is to provide a repair that is free from recurrence, pain, and infection, with minimal scarring and with improvement in patient's quality of life [1]. In the

Correspondence to: Dr. Mohammed A. Elharty,

The Department General Surgery, Faculty of Medicine,

Tanta University, Egypt traditional Lichtenstein procedure, the mesh is fixed in position with sutures to prevent migration [2]. The widespread use of this technique has reduced the hernia recurrence rates to acceptable levels (less than $2 \%$ ). The rate of chronic pain following hernia repair ranges from $11-40 \%$, so the focus of scientific attention has shifted towards prevention of postoperative pain [3]. The reason for chronic pain is multi-factorial; the type of mesh material, the nerve irritation or injury, the nerve entrapment by the fixation sutures, or the inflammatory reaction by the mesh have all been reported as possible causes. Different fixation procedures using absorbable sutures and skin staples were investigated [4].

Type of mesh may play a role in the postoperative pain. The lightweight mesh did not produce post-operative pain, foreign body sensation or pain during exercise and movement [2]. It is documented that the conventional polypropylene mesh and sutures for fixation are associated with formation of mesh aponeurosis scar tissue complex as an inflammatory response induced by polypropylene material [5]. Any mesh should have the usual properties of any implant, including being non-allergenic, non-carcinogenic, have good incorporation into tissue it is replacing or reinforcing [6]

In 2008, Covidien launched self gripping (parietex ${ }^{\circledR}$ progrip $\AA$ ) mesh indicated for the use in inguinal hernia and incisional hernia repairs, to offer patients greater comfort following surgery, and allow surgeons the ability to position and secure the mesh and reduction of the of the operation time [7]. It is an isoelastic large pore knitted fabric of monofilament polyester that incorporates biodegradable polylactic acid (PLA) progrips. These microgrips are club shaped $1 \mathrm{~mm}$ projections, they integrate into the tissue for $0.5 \mathrm{~mm}$ below the 
lower rim of the mesh and provide stronger tissue incorporation at 5 days than fixation by staples [8] Fig. (1) its density is $74 \mathrm{~g} / \mathrm{m}^{2}$ at implantation and $38 \mathrm{~g} / \mathrm{m}^{2}$ after absorption [9]. It is approximately $45 \%$ lighter than standard polypropylene mesh $\left(38 \mathrm{~g} / \mathrm{m}^{2}\right.$ versus $\left.85 \mathrm{~g} / \mathrm{m}^{2}\right)$ [3]

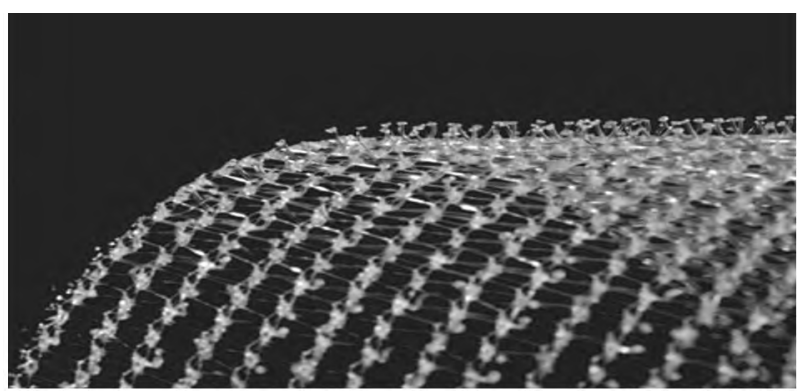

Fig. (1): Parietex ${ }^{\circledR}$ progrip ${ }^{\circledR}$ mesh absorbable microgrips for fixation [2]

\section{Patients and Methods}

\section{Patients:}

This prospective study was conducted on 26 adult male patients presented with primary reducible inguinal hernia who were admitted into the Surgical Oncology Unit at General Surgery Department, Tanta University Hospital from August 2017 to July 2018. Patients were randomized into 2 groups; Control group, group A. The 1 st 10 cases underwent inguinal hernia repair with polypropylene ${ }^{\circledR}$ mesh and group $B$, the subsequent 16 cases who underwent inguinal hernia repair with self gripping (Parietex $\left.{ }^{\circledR}\right)$ mesh.

\section{Inclusion criteria:}

Adult male patients 18 years or older with primary reducible inguinal hernia.

\section{Exclusion criteria:}

- Patients younger than 18 years.

- Complicated inguinal hernia.

- Recurrent inguinal hernia.

- Female patients.

The details of the operation technique and complications were explained to the patient and an informed written consent was obtained. Approval by the ethical committee for research in Tanta Faculty of medicine was obtained before initiating this study.

\section{Preoperative workup:}

Every patient was subjected to:

1- History taking: Age, sex, occupation, special habits, reducibility, duration.
A particular stress was made upon risk factors of inguinal hernia as smoking, heavy weight lifting and the nature of patient's work, chronic cough, chronic constipation, bladder neck obstruction, body mass index (BMI) $>25$ and history of appendectomy.

\section{2- Examination:}

- General: Vital data (blood pressure, pulse and temperature) and general condition.

- Local: To define type of the hernia and/or complications.

Checking the other hernia orifices, presence of organomegaly and the cardiopulmonary status.

\section{3- Investigation:}

a- Laboratory: Routine laboratory investigations as: Complete blood analysis, renal function tests.

b- Imaging:

- Chest X-ray.

- Pelvi abdominal U/S to exclude organomegally, abdominal masses or prostatic enlargement.

\section{Patient preparation:}

In every patient, the operative area swabbed with betadine the night before surgery.

Prophylactic antibiotics: (Amoxycillin + clavulanic acid) IV were given 2 hours before induction of anesthesia and a second dose 12 hrs later.

\section{Operative details:}

Operations were performed under spinal or general anesthesia with the patients in supine position. Skin disinfection was done with $10 \%$ povidine iodine antiseptic solution.

Skin incision was made $1 / 2$ inch above the medial $2 / 3$ of the inguinal ligament to expose the external oblique aponeurosis, then it was divided.

The cord is dissected out of its bed to obtain a suitable space for mesh positioning deep to the external oblique aponeurosis.

Dissection of the hernia sac from the spermatic cord was gently done. In case of indirect oblique hernia, the sac was dissected from the cord till its proper neck, then the sac was excised after transfixing-ligation of its neck by absorbable suture material (Vicryl 0). In case of direct hernia, the sac was reduced without opening. 


\section{Mesh fixation:}

Group A: A sheet of polypro- pylene ${ }^{\circledR}$ (PP) mesh tailored to shape the posterior wall of the inguinal canal where it is placed, so that it overlapped the pubic tubercle by at least $1 \mathrm{~cm}$ medially. Fixed with interrupted polypropylene $2 / 0$ suture to the inguinal ligament inferiorly and interrupted sutures to the conjoint tendon superiorly. A slit is made for the spermatic cord and the tails secured back together around the cord with permanent sutures (Lichtenstein in 1984)

Group B: A 6x11 cm Parietex ${ }^{\circledR}$ progrip ${ }^{\circledR}$ mesh was laid over the posterior wall of the inguinal canal and tailoring of the mesh was done to accommodate the created space overlapped the pubic tubercle minimally by $1 \mathrm{~cm}$. Fixation was done by applying digital pressure on the mesh, starting medially on the pubic bone, then laterally onto the conjoint tendon. To help the mesh positioning, one stitch of absorbable suture to be taken to fix it to the pubic tubercle.

Closure: The external oblique aponeurosis was then closed anterior to the spermatic cord structures by non-absorbable suture. The subcutaneous tissue was approximated by an absorbable sutures (vicryl $2 / 0$ ) and skin was closed by non absorbable subcuticular sutures. No drainage system was needed.

\section{Recovery and postoperative care:}

Patients were monitored in a recovery room for a minimum 2 hours. Non-narcotic injectable analgesic ( $75 \mathrm{mg}$ diclofenac sodium intra muscular) was given routinely to every patients in the immediate post operative period and converted to oral tablets on the next morning.

Follow-up:

Every patient is followed-up monthly for the first 3 months then every 6 months till the end of the study.

On every follow-up visit the patient is:

1- Clinically well assessed for presence of signs of:

- Early post-operative complications (that occur within 30 days after surgery) e.g: Local inflammation, swelling as seroma, recurrence or tenderness [10].

- Late post-operative complications (that occur after 30 days after surgery) e.g: Chronic groin pain, mesh infection or testicular atrophy.

2- Inguinal ultra-sonographic study at the 6th month post-operatively to check the stability and integrity of the mesh or excessive scarring.

\section{Methods of evaluation:}

A- The surgeon and the surgery:

1- Technical difficulties as in cases of disturbed anatomy and obese patients.

2- Operative time.

3- Mesh fixation time.

\section{B- The patient:}

1- Post operative pain, using visual analogue scale (VAS) and the needed analgesic dose to kill pain [11]

2- Hospital stay.

3- Return to normal activity.

4- Patient satisfaction.

\section{C- The mesh itself and related complications:}

1- Seroma detected clinically.

2- Hematoma, detected clinically.

3- Wound infection (superficial/deep) according to Centre for Disease Control (CDC) definition of Surgical Site Infection (SSI).

4- Mesh infection.

5- Recurrence. Clinically and as confirmed by $\mathrm{U} / \mathrm{S}$.

6- Thickening of the spermatic cord and testicular atrophy assessed by U/S.

7- Foreign body sensation.

8- Mesh shrinkage as assessed by U/S.

9- Cost.

\section{Visual analogue scale (VAS):}

The pain VAS is self completed by the respondent. The respondents are asked to place a line perpendicular to the VAS line at the point that represents their pain intensity.

\section{Scoring:}

Using a ruler, the score is determined by measuring the distance $(\mathrm{mm})$ on the $10 \mathrm{~cm}$ line between the "no pain" anchor and the patient's mark providing a range of scores from 0-100 and determine the degree of pain as following: None $(0-4 \mathrm{~mm})$, mild $(5-44 \mathrm{~mm})$, moderate $(45-74 \mathrm{~mm})$ and severe (75-100mm) [11] Fig. (2).

1-10 Numeric pain rating scale

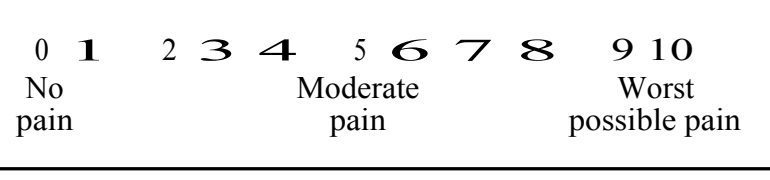

Fig. (2): Visual analogue scale [12] 


\section{Results}

This study was a prospective, randomized, controlled study. It included twenty six adult male patients who were admitted into the Surgical Oncology Unit at General Surgery Department in Tanta University Hospital for elective repair of uncomplicated inguinal hernia during the period from the 1 st of August 2017 to the end of July 2018.

The patients were randomized into group A (Conventional polypropylene ${ }^{\circledR}$ mesh) and group B (Parietex ${ }^{\circledR}$ Progrip ${ }^{\circledR}$ mesh).

Group A: Five patients (50\%) had a right side hernia while five patients $(50 \%)$ had a left side one. Six of them $(60 \%)$ had an IIH while three patients $(30 \%)$ had a $\mathrm{DIH}$, and only one patient $(10 \%)$ had pantaloon hernia. Four patients $(40 \%)$

U/S findings:

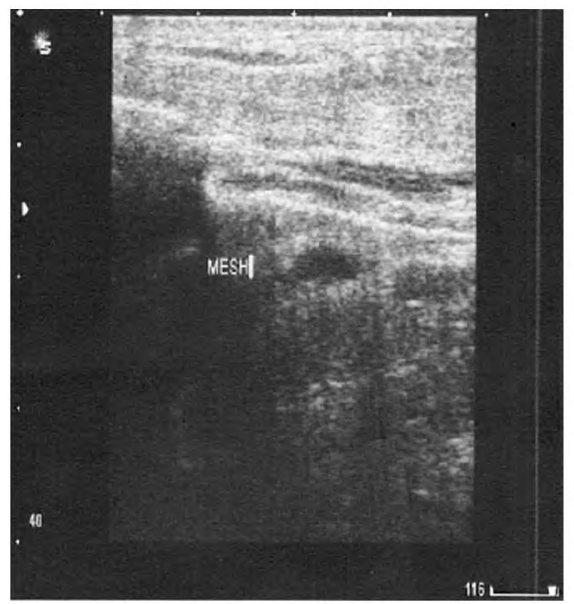

Fig. (3): U/S of the left inguinal region showing self gripping (parietex ${ }^{\circledR}$ progrip $\AA$ ) mesh in 33 yrs old male patient after one month post surgery.

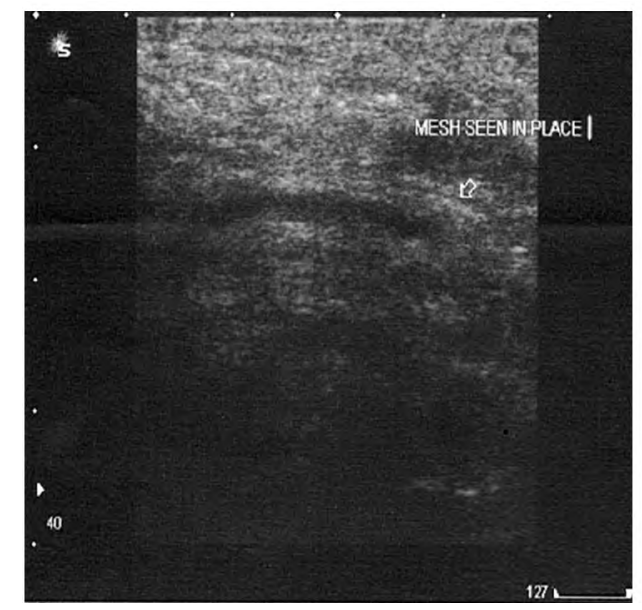

Fig. (5): U/S of right inguinal region showing Polypropylene ${ }^{\circledR}$ mesh in 45 yrs old male patient after one month post surgery. had history of other side hernia repair with polypropylene ${ }^{\circledR}$ mesh.

Group B: Including sixteen patients who underwent inguinal hernia repair with self gripping (Parietex ${ }^{\circledR}$ Progrip $\left.{ }^{\circledR}\right)$ mesh. Eight patients $(50 \%)$ had a right sided hernia while eight patients $(50 \%)$ had a left side one. Fourteen patients $(87.5 \%)$ had an indirect inguinal hernia (IIH) while two patients $(12.5 \%)$ had a direct inguinal hernia (DIH). Two patients $(12.5 \%)$ had a history of other side hernia repair using polypropylene ${ }^{\circledR}$ mesh Tables $(1,2)$.

Pain necissates administration of non steroidal analgesic in the form of Brufen $400 \mathrm{mg}$ tablets one tablet every $8 \mathrm{hrs}$. They responded well within one week without need to increase dose except only one patient in group A (10\%) required increasing the dose to $600 \mathrm{mg}$ tablets one tablet every $8 \mathrm{hrs}$ till pain disappeared over 10 weeks.

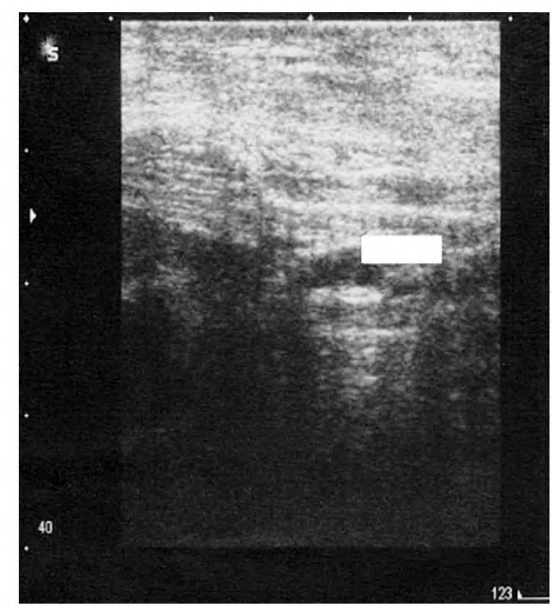

Fig. (4): U/S of the left inguinal region showing self gripping (Parietex ${ }^{\circledR}$ progrip $\AA$ ) mesh in 33 yrs old male patient after 6 months post surgery.

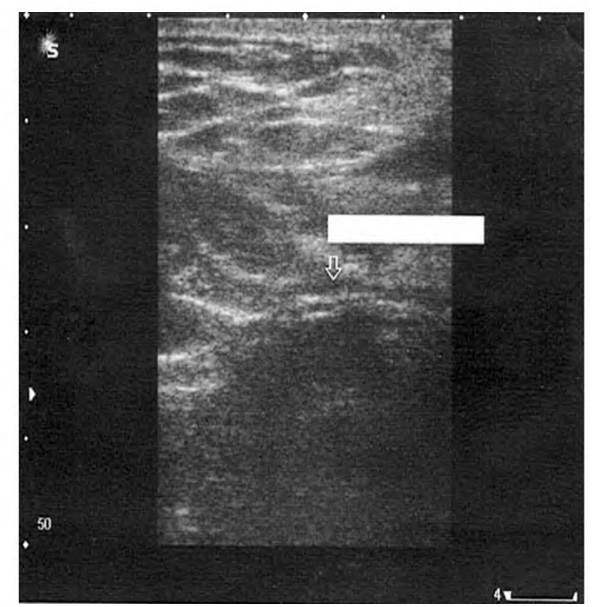

Fig. (6): U/S of right inguinal region showing Polypropylene® mesh in 45 yrs old male patient after 6 months post surgery. 
Table (1): Demographic data of the studied cases in both groups.

\begin{tabular}{|c|c|c|c|c|c|c|}
\hline & \multicolumn{2}{|c|}{$\begin{array}{c}\text { Group A } \\
(\mathrm{n}=10)\end{array}$} & \multicolumn{2}{|c|}{$\underset{(n=16)}{\text { Group B }}$} & \multirow{2}{*}{$\begin{array}{c}\text { Test of } \\
\text { significance }\end{array}$} & \multirow[t]{2}{*}{$p$} \\
\hline & No. & $\%$ & No. & $\%$ & & \\
\hline \multicolumn{7}{|l|}{ Age: } \\
\hline Min-Max & \multicolumn{2}{|c|}{$22.0-63.0$} & \multicolumn{2}{|c|}{$20.0-61.0$} & \multirow[t]{3}{*}{$t=1.359$} & \multirow[t]{3}{*}{0.187} \\
\hline Mean \pm SD & \multicolumn{2}{|c|}{$46.40-13.75$} & \multicolumn{2}{|c|}{$39.25-12.61$} & & \\
\hline Median & \multicolumn{2}{|c|}{47.5} & \multicolumn{2}{|c|}{41.0} & & \\
\hline \multicolumn{7}{|l|}{ BMI: } \\
\hline Min-Max & \multicolumn{2}{|c|}{$24.6-36.0$} & \multicolumn{2}{|c|}{$23.66-38.97$} & \multirow[t]{3}{*}{$t=0.139$} & \multirow[t]{3}{*}{0.890} \\
\hline Mean \pm SD & & & & & & \\
\hline Median & \multicolumn{2}{|c|}{28.55} & \multicolumn{2}{|c|}{28.55} & & \\
\hline \multicolumn{7}{|l|}{ Occupation: } \\
\hline Manual worker & 8 & 80.0 & 11 & 68.8 & $\chi^{2}=2.650$ & $\mathrm{MC}_{p}=0.250$ \\
\hline Student & 1 & 10.0 & 0 & 0 & & \\
\hline Employee & 1 & 10.0 & 5 & 31.2 & & \\
\hline \multicolumn{7}{|l|}{ Medical History: } \\
\hline No & 2 & 20.0 & 6 & 37.5 & \multirow{4}{*}{$\begin{array}{l}\chi_{2}^{2}=0.885 \\
\chi_{2}=2.666 \\
\chi=0.394\end{array}$} & \multirow{4}{*}{$\begin{array}{l}\mathrm{FE} p=0.420 \\
\mathrm{FE}_{p}=0.264 \\
\mathrm{FE}_{p}=0.689\end{array}$} \\
\hline Yes & 8 & 80.0 & 10 & 62.5 & & \\
\hline DM & 3 & 30.0 & 1 & 6.3 & & \\
\hline Chest problems & 5 & 50.0 & 10 & 62.5 & & \\
\hline \multicolumn{7}{|l|}{ Surgical History: } \\
\hline No & 4 & 40.0 & 9 & 56.3 & $\chi^{2}=5.439$ & $\mathrm{MC}_{p}=0.250$ \\
\hline Appendectomy & 2 & 20.0 & 1 & 6.3 & & \\
\hline Other hernia side repair & 4 & 40.0 & 2 & 12.5 & & \\
\hline Other surgeries & 0 & 0.00 & 4 & 25.0 & & \\
\hline
\end{tabular}

Table (2): Total operative time, mesh fixation time, complications and postoperative pain of the studied cases in both groups.

\begin{tabular}{|c|c|c|c|c|c|c|}
\hline & \multicolumn{2}{|c|}{$\begin{array}{c}\text { Group A } \\
(\mathrm{n}=10)\end{array}$} & \multicolumn{2}{|c|}{$\underset{(n=16)}{\text { Group B }}$} & \multirow{2}{*}{$\begin{array}{c}\text { Test of } \\
\text { significance }\end{array}$} & \multirow[t]{2}{*}{$p$} \\
\hline & No. & $\%$ & No. & $\%$ & & \\
\hline $\begin{array}{l}\text { Total operative time: } \\
\text { Min-Max } \\
\text { Mean } \pm \text { SD } \\
\text { Median }\end{array}$ & \multicolumn{2}{|c|}{$\begin{array}{c}55.0-75.0 \\
65.50 \pm 7.06 \\
64.0\end{array}$} & \multicolumn{2}{|c|}{$\begin{array}{c}40.0-55.0 \\
46.81 \pm 5.37 \\
\quad 46.0\end{array}$} & $t=7.652$ & $<0.001$ \\
\hline $\begin{array}{l}\text { Mesh fixation time: } \\
\text { Min-Max } \\
\text { Mean } \pm \text { SD } \\
\text { Median }\end{array}$ & \multicolumn{2}{|c|}{$\begin{array}{c}13.0-18.0 \\
15.3 \pm 1.49 \\
15.0\end{array}$} & \multicolumn{2}{|c|}{$\begin{array}{c}3.0-7.0 \\
5.13 \pm 109 \\
5.0\end{array}$} & $t=20.099$ & $<0.001$ \\
\hline $\begin{array}{l}\text { Early complications: } \\
\text { No } \\
\text { Yes } \\
\text { Scrotal oedema } \\
\text { Seroma } \\
\text { Wound infection } \\
\text { Haematoma } \\
\text { Recurrence }\end{array}$ & $\begin{array}{l}2 \\
8 \\
7 \\
3 \\
2 \\
0 \\
0\end{array}$ & $\begin{array}{l}20.0 \\
80.0 \\
70.0 \\
30.0 \\
20.0 \\
0.0 \\
0.0\end{array}$ & $\begin{array}{l}10 \\
6 \\
4 \\
2 \\
0 \\
0 \\
0\end{array}$ & $\begin{array}{l}62.5 \\
37.5 \\
25.0 \\
12.5 \\
0.0 \\
0.0 \\
0.0\end{array}$ & $\begin{array}{c}\chi_{2}^{2}=4.473 \\
\chi_{2}=5.105 \\
\chi_{2}=1.213 \\
\chi=3.467 \\
-\end{array}$ & $\begin{aligned} \mathrm{FE}_{p} & =0.051 \\
\mathrm{FE}_{p} & =0.043 \\
\mathrm{FE}_{p} & =0.340 \\
\mathrm{FE}_{p} & =0.138 \\
& -\end{aligned}$ \\
\hline $\begin{array}{l}\text { Late complications: } \\
\text { Epididymo-orchitis } \\
\text { Testicular atrophy }\end{array}$ & $\begin{array}{l}0 \\
0\end{array}$ & $\begin{array}{l}0.0 \\
0.0\end{array}$ & $\begin{array}{l}0 \\
0\end{array}$ & $\begin{array}{l}0.0 \\
0.0\end{array}$ & - & - \\
\hline $\begin{array}{l}\text { Pain according to VAS: } \\
\text { None } \\
\text { Mild } \\
\text { Moderate } \\
\text { Severe }\end{array}$ & $\begin{array}{l}9 \\
1 \\
0 \\
0\end{array}$ & $\begin{array}{l}90.0 \\
10.0 \\
0.0 \\
0.0\end{array}$ & $\begin{array}{l}16 \\
0 \\
0 \\
0\end{array}$ & $\begin{array}{l}100.0 \\
0.0 \\
0.0 \\
0.0\end{array}$ & $\chi^{2}=1.664$ & $\mathrm{FE}_{p}=0.385$ \\
\hline $\begin{array}{l}\text { Analgesia: } \\
\quad \text { No need } \\
\text { Need } \\
\text { Regular dose } \\
\text { Over dose }\end{array}$ & $\begin{array}{l}9 \\
1 \\
9 \\
1\end{array}$ & $\begin{array}{r}90.0 \\
10.0 \\
90.0 \\
10.0\end{array}$ & $\begin{array}{l}16 \\
0 \\
16 \\
0\end{array}$ & $\begin{array}{l}100.0 \\
0.0 \\
100.0 \\
0.0\end{array}$ & $\chi^{2}=1.664$ & $\mathrm{FE}_{p}=0.385$ \\
\hline
\end{tabular}




\section{Discussion}

This study was designed to assess the outcome of self gripping mesh versus the conventional sutured mesh.

In group $\mathrm{A}$, the ages ranged from $22-63$ years with a median of 47.0 years. In group B, the ages ranged from 20-61 years with a median of 41.0 years. There was no statistically significant difference between both groups regarding age $(p=0.187)$. This is the usual age at repair as reported by Maharaul $\mathrm{H}$ et al., [s. Verhagen $\mathrm{T}$ and colleagues [3]

In this study BMI $>25 \%$ was a risk factor for inguinal hernia in both groups. In group A, it ranged from $24.60-36.0 \mathrm{Kg} / \mathrm{m}^{2}$ with mean $29.20 \pm 4.13$ $\mathrm{Kg} / \mathrm{m}^{2}$ and median $28.55 \mathrm{Kg} / \mathrm{m}^{2}$ and In group B, it ranged from $23.66-38.97 \mathrm{Kg} / \mathrm{m}^{2}$ with mean 29.44 $\pm 4.41 \mathrm{Kg} / \mathrm{m}^{2}$ and median $28.55 \mathrm{Kg} / \mathrm{m}^{2}$. This is comparable with the findings of Ceith $\mathrm{N}$ and colleagues [13] . and Verhagen T et al., [3] who reported that the median BMI in both groups was $25 \mathrm{Kg} / \mathrm{m}^{2}$.

In the current study: 5 cases (50\%) in group $\mathrm{A}$ and 10 cases $(62.5 \%)$ in group B were smokers and had chest problems. Whereas, Verhagen $\mathrm{T}$ and colleagues [3] reported $28 \%$ of patients in self gripping mesh group and $23.75 \%$ in sutured mesh group were smokers and had chest problems. Kingsnorth A and his group [2] reported that $27.9 \%$ of cases were smokers and had chest problems. In their series, Zhang $\mathrm{C}$ and colleagues [4] reported $57.04 \%$ in the self gripping mesh group and $29.2 \%$ in sutured mesh group were smokers and had chest problems.

As regard co-morbidity, we reported that 3 patients (30\%) in group A and one patient (6.3\%) in group B were diabetics. This is comparable with the finding of Kingsnorth A et al., [2] who reported that $6 \%$ of their cases were diabetics.

As regard the operative time (calculated from skin incision to skin closure); in group A, it ranged from 55-75 minutes with a mean of $65.5 \pm 7.06$ minutes. However, in group B it ranged from 4055 minutes with a mean of $46.81 \pm 5.37$ minutes, with reduction in the operative time ranged 15-20 minutes. The operative time in group B was statistically significantly shorter than it in group A $(p<0.001)$.

As regard the time needed for mesh fixation; in group A, it ranged from 13-18 minutes with a mean of $15.3 \pm 1.49$ minutes, whereas in group $B$, it ranged from 3-7 minutes with a mean of 5. 13 \pm 1.09 minutes. The mesh fixation time was signif- icantly shorter in group B $(p<0.001)$. These results are consistent with the results of Batabyal $\mathrm{P}$ et al., [14]. Maharaul $\mathrm{H}$ et al., [я. For surprise, Anadol A $\mathrm{Z}$ et al., [1s found no significant difference in the operative time between using self gripping mesh and mesh fixation by conventional sutures.

The incidence of seroma in our study was 3 patients (30\%) in group A and 2 patients (12.6\%) in group B. All the 5 patients who developed mild seroma had an indirect inguino-scrotal hernia with larger sac that required more distal dissection creating large surface area and large dead space which may be the reasons of seromas formation. These seromas resolved spontaneously without any intervention in all cases during the first few post operative days.

In the present study; 7 cases $(70 \%)$ in group A and 4 cases (24\%) in group B developed mild scrotal edema that resolved spontaneously during the few post operative days. While, Batabyal $\mathrm{P}$ et al., [14] . reported that scrotal edema was $2 \%$ in patients who underwent inguinal hernia repair with self gripping mesh.

In the present study, we reported wound infection in 2 cases (were diabetics) in group A during the first few postoperative days that resolved on antibiotics. No reported cases with wound infection in group B. In our study, over the short period of follow-up, we reported no recurrence in either group. Therefore, long term follow-up can judge the recurrence as some studies said that if recurrence to occur, most incidence supposed to be within 2 yrs after operation $[8,16]$

On ultrasound study during the follow-up period, we reported no mesh complications in terms of shrinkage, migration or fragmentation. However, migration to a great extent depends on the nature of mesh and the type of fixation of the mesh. An experimental study in rats comparing polypropylene, polyglactin and mixed polypropylene-polyglactin mesh revealed frequent and deeper penetration of bladder by polypropylene one. It is found erosion of polypropylene into the muscularis mucosa of bladder within 14 days [17] .

Regarding postoperative pain and need for analgesia, in our study there was only one patient $(10 \%)$ in group A had mild pain for 3 months postoperatively that required increasing the dose of analgesia. While, no reported cases of chronic groin pain in group B. There was no statistically significant difference between both groups $(p=0.385)$. Zhang $\mathrm{C}$ et al., [4]. Junsheng $\mathrm{Li}$ and colleagues [8] and Verhagen T et al., [я. also re- 
ported no statistically significant differences in pain intensity between the two groups with $p$-value $=0.40,0.25,0.016$ respectively.

Contrary to the other reports, El-Komy $\mathrm{H}$ and colleagues [18] reported that the mean VAS scores for the self gripping mesh group were consistently significantly higher than those in the sutured mesh group. They found that, after 2 months sutured mesh patients cured from pain whereas $75 \%$ of self gripping mesh patients still have pain especially with movement.

\section{Conclusion:}

The self gripping mesh proved to be as safe and effective as the conventional sutured polypropylene mesh in Lichtenstein tension free repair of uncomplicated inguinal hernia. There was no difference between the two meshes used as regard to the technical difficulties and surgeons were equally satisfied.

There was no difference between the two meshes used as regard the post operative complications such as seroma, hematoma, wound infection and mesh complications in terms of shrinkage, migration, fragmentation indicates that both types of mesh are effective and safe.

The mesh fixation time and the overall operative time were significantly shorter with self gripping mesh than with the sutured one.

Self gripping mesh hocks proved to be as effective and safe as sutures in fixing the mesh in place. As there was no recurrence was reported in both groups during the follow-up period, also there was no statistically significant difference between both groups regarding postoperative chronic pain and need for analgesia. $(p=0.385)$.

The higher price of self gripping mesh compared with conventional mesh makes its use questionable. The self gripping mesh costs 22 times that of the polypropylene mesh; 4500LE vs750 LE. This may be the most limitation factor of its wide spread use.

The smaller number of the studied cases (26) together with the short time of follow-up (6 months) make us unable to give solid recommendation to use one mesh type than the other.

\section{References}

1- CHASTAN P.: Tension-free open hernia repair using an innovative self-gripping semi-resorbable mesh. Hernia., 13: 137-142, 2009.
2- KINGSNORTH A., GINGELL L.M., NIENHUIJS S., et al.: Randomized controlled multicenter international clinical trial of self-gripping Parietex ${ }^{\mathrm{TM}}$ ProGrip ${ }^{\mathrm{TM}}$ polyester mesh versus lightweight polypropylene mesh in open inguinal hernia repair: Interim results at 3 months. Hernia, 16: 287-294, 2012.

3- VERHAGEN T., ZWAANS W., LOOS M., et al.: Randomized clinical trial comparing self-gripping mesh with a standard polypropylene mesh for open inguinal hernia repair. BJS., 103: 812-818, 2016.

4- ZHANG C., FENGHE L.I., ZHANG H., et al.: Selfgripping versus sutured mesh for open inguinal hernia repair: A systematic review and meta-analysis of current literature. J. Surg. Res., 185: 653-660, 2013.

5- MAHARAUL H., SHORY V. and JOSHI S.: Comparison of pro-grip mesh v/s conventional mesh in Lichtenstein inguinal hernia repair. Inter. J. Biomed Res., 7 (10): 738 742, 2016

6- ANDREW C. and DE BEAUX: Abdominal hernias, in Simon Paterson Brown: Core topics in general and emergency surgery 5 th ed, Elsevier Churchill Livingstone, UK, Chapter 4: 57-80, 2014.

7- YILMAZ A., YENER O., KAYNAK B., et al.: Selfgripping CovidienTM ProGripTM Mesh versus polypropylene mesh in open inguinal hernia repair: Multicenter short term results. Prague. Medical. Report, 114: 231-238, 2013.

8- JUNSHENG L.I., ZHENLING J.I. and YINXIANG L.I.: The comparison of Self-Gripping mesh and sutured mesh in open inguinal hernia repair: The results of meta-analysis. Ann. Surg., 259: 1080-1085, 2014.

9- SANDERS D.L., NIENHUIJS S., ZIPRIN P., et al.: Randomized clinical trial comparing self-gripping mesh with suture fixation of lightweight polypropylene mesh in open inguinal hernia repair BJS, 101: 1373-1382, 2014.

10- ERIC M.P. and RYAN M.J.: Managing complications of open hernia repair, in Yuri W Novitsky: Hernia Surgery current principles, Springer, USA, Chapter 20: 210, 2016.

11- GILLIAN A.H., SAMRA M., TETYANA K., et al.: Measures of adult pain visual analog scale for pain (VAS Pain), numeric rating scale for pain (nrs pain), mcgill pain questionnaire (MPQ), Short-Form McGill Pain Questionnaire (SF-MPQ), Chronic Pain Grade Scale (CPGS), Short Form-36 Bodily Pain Scale (SF-36 BPS), and measure of intermittent and constant osteoarthritis pain (ICOAP). Arthritis Care \& Research, 63 (11): 240-252, 2011.

12-VIGHNESH D., MANISHA D., VIVEK H., et al.: Clinical evaluation of conventional and laser tooth preparation using visual analogue scale. Journal of Dental Laser, 7 (1): 27-29, 2013.

13- CEITH N., VAASNA T., MURRUSTE M., et al.: Singlecenter, single-blinded, randomized study of self-gripping versus sutured mesh in open inguinal hernia repair. J. Surg. Res., 194: 77-82, 2015.

14- BATABYAL P., HADDAD R., JASWINDER S., et al. Inguinal hernia repair with Parietex Progrip mesh causes minimal discomfort and allows early return to normal activities. The. Am. J. Surg., 211: 24-30, 2016.

15- ANADOL A.Z., AKIN M., KURUKAHVECIOGLU O., et al.: A prospective comparative study of the efficacy of 
conventional Lichtenstein versus self-adhesive mesh repair for inguinal hernia. Surg. Today, 41: 1498-1503, 2011.

16- MARK A.M. and MICHAEL J.R.: Hernias, in Courtney M. Townsend, Daniel R. Beauchamp, Kenneth L. Mattox, et al.: Sabiston textbook of surgery, the biological basis modern surgical practice 18 th ed, elsevier, USA, Chapter 44: 1155-1178, 2008.
17- AGRAWAL A and. AVILL R.: Mesh migration following repair of inguinal hernia: A case reportand review of literature. Hernia., 29 (5): 24-28, 2005.

18- EL-KOMY H., EL-GENDI A., ABDEL-SALAM W., et al.: Self-fixing parietex progrip versus the standard sutured prolene mesh in tension-free repair of inguinal hernia: Effect on testicular volume and testicular blood flow. Updates in Surgery, Italian Society of Surgery (SIC). https://doi.org/10.1007/s13304-018-0554-0, 2018.

\section{دراسة مستقبلية فى تقييم كفاءة الشبكة ذاتية التثبيت

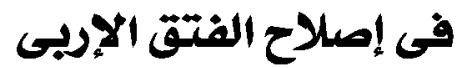

يعتبر إصلاح الفتق الإربى من أكثر الجراحات المنتثرة فى العالم حيث يتم إصلاحه إما عن طريق إصلاح|لفتحة فى جدار البطن عن طريق

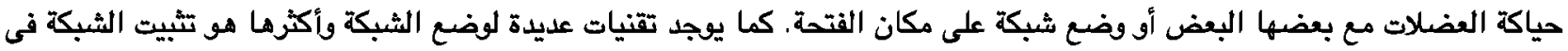

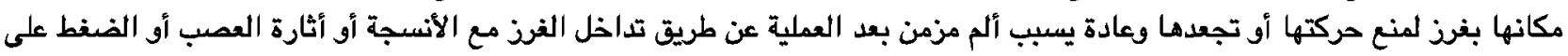

إن الثبكة ذاتية التبيت (برياتكس) صممت لتجنب تثبيت الثبكة بالغرز وذلك لتقليل حدوث التليف بعد التثييت أثثاء الإلتئام وتقليل الألم بعد العملية وهى ثبكة خفيفة الونن محبة للماء من مادة البولى إستر كما تتمتع بجود نوائد خطافية تمكنها من الألتصاق بقوة بالأنسجة والعضلات والإستفناء عن وبائل التثبيت الثقليدية.

أجريت هذه الدراسة على حبمريض ممن يعانون من الفتق الإربى بوحدة جراحة الأودام بقسم الجراحة العامة مستثفى طنطا الجامعى

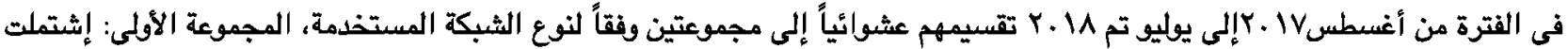
على • أمرضى تلقوا ثبكة البرولين وأستخدمت الخيوط الجيو الجراحية لتبيها والمجموعة الثانية: إثتملت على 77 امريضاً حيث تم إستخدام الشبكة

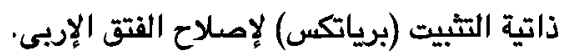

كانت مدة تثبيت الثبكة والوقت الكلى للجراحة أقصر بكثير بإستخدام الثبكة ذاتية التشبيت مما كانت عليه بإستخدام ثبكة البرلين ولا يوجد فرق ذات دلالات إحصائية في معدل الألم، المضاعفات المبكرة والمتأخرة بعد المبك العملية. 